\title{
A Reflection on Chinese "Chi": From the Perspective of Cognitive Linguistics
}

\author{
Bin Wang \\ Beijing University of Posts and Telecommunications, Beijing, China \\ Fan Zhang \\ Beijing University of Posts and Telecommunications, Beijing, China \\ Email: finesandy@126.com
}

\begin{abstract}
Chinese language, for Chinese stems from hieroglyphics and phonogram. The character corresponds with the pronunciation, written form and meaning. The word is in the first phase of the character to actualize the grammaticalization. This paper, from the perspective of cognitive linguistics, analyzes the character "Chi" by prototype category, and the word about "Chi" by lexical formation. It also interprets that the formations of image schema and metaphor mechanism result in the emerging of many words about "Chi" and their corresponding meanings. This paper holds that cognitive linguistics can give a reasonable interpretation about one character with many meanings and its relative words with different meanings. The proficiency of cognitive linguistics can guide and help Chinese teaching for foreigners, natural language processing and automatic machine translation.
\end{abstract}

Index Terms - "Chi” and prototype category, "Chi” and lexical formation, image schema, metaphor

\section{INTRODUCTION}

What's the smallest structural unit of Chinese? "“Character' is the answer", Zhao Yuanren, a prominent linguist, claims that, "Chinese character has a similar status as word in Indo-European language, but this never means they have similar or even the same structure (Zhao Yuanren, 1975. P241)". What's 'character'? Some believe it refers to the square writing form; others hold it is the smallest reasonable structural unit of language. The Literary Mind and the Carving of Dragons (Wén Xīn Diāo Lóng) also recorded that 'a sentence consists in characters'. The hierarchical structure of Chinese language is character, character group (or word), phrase, clause, and sentence. Based on a square writing form, one character represents one syllable and usually one morpheme. Hence, the character corresponds with the pronunciation, form and meaning (note: one morpheme with two or more syllables is so uncommon that they can be listed out such as Pútáo (grape), Pósuō (dancing), Pánghuáng (hesitate)). In view of the relevancy of pronunciation and meaning, Xu Tongqiang defines character as a structural unit linking one syllable with one concept.

The word is in the first phase of grammaticalizing the character. Most of Chinese two-syllable words are composed of modifier-head, verb-object, verb-complement, or subject-predicate constructions. They can be grammaticalized by endocentric, exocentric or concentric devices. For instances, the character "shù"(tree) can form "sōngshù"(pine tree), "sāng shù"(mulberry tree), "táoshù"(peach tree), "lüshuù"(willow) etc. by endocentric device; it can form "shùgàn"(trunk), "shùyè"(leaf), "shùzhî"(branch), "shùchà"(twig) etc. by exocentric device; likewise, it composes "shùmù"(wood) or "shùlín"( forest) by concentric way. This thesis, from the perspective of cognitive linguistics, will analyze Chinese character "Chi" and words about "Chi" to further explain why words about "Chi" are so abundant.

\section{The Prototype CATEGORY OF "CHI"}

According to cognitive linguistics, knowledge in form of network is preserved in our mind. In this network, some knowledge is in central position and hence is called prototype, easy to be mentioned and remembered, while other is in marginal place. Each character has a semantic category, including central meaning and marginal meaning. The central meaning is a prototype of the semantic category, which is firstly acquired and known as the denotative meaning. The category is built upon meaning extension. Take character "Chi" for example, in Modern Chinese Dictionary, the basic meaning of "Chi" is (1)put solid or liquid food into mouth to digest and swallow down, or to suck and drink. E.g. "chīyào" (take medicine), "chīfàn(eat food), "chīchá"(drink tea); the place, tableware, or food portion are involved when taking food, so "Chi" derives other extended meanings via metaphor mapping system (2)eat in a place selling food, or eat in accordance with portion or standard. E.g. "chī shítáng" (eat in canteen), "chī guănzi" (eat in a restaurant), "chī dàzào" or "chī dàguōfàn" (everyone eats in big pot to show egalitarian), "chī xiăozào" (someone eats in small pot and gets special treatment); due to Chinese's traditional view that food is such a basic necessity that it's a primary matter to be solved in every walk of life. Therefore, "Chi" extends the third meaning (3) to make a live relied on something. E.g. "chī lăo běn" (rest on one's laurels/ to live on previously accumulated wealth), "chī shān" and "chī shư̌" (if a man lives 
on a mountain, he will live off the mountain/ if a man lives by the water, he will live off the water), "chī lăobăo" (live on labor security funds), "chī jiùjì" (live by government's relief), “chī fùmǔ” (rely on parents), "chī gōngz $\overline{1} ”$ (live by support of one's salary); if one does well in his job, he or she will "chī xiāng" or "chīde kāi”" (win recognition from people because of his or her competence in a position); on the contrary, if one does worse in his job, he or she will "bù chīxiāng" or "chī bùkāi"; moreover, we need put food into mouth when eating, so "Chi”" gets the fourth meaning (4) something is put into another thing. E.g. "chī shuî" (the depth of boat entering the water), "chī qián" (money in the card is deducted without reason), "chī qiāngzî" (a bullet is shot into one's body); when putting food into the mouth, we need chew in order to digest and absorb it. Then Chi leads the fifth meaning (5)absorb. E.g. "chīyóu" (machine works after absorbing oil), "chī mó" (ink is absorb into paper); "absorb" metaphorically extends the sixth meaning (6)grasp or understand. E.g. "chī bútóu" (one cannot understand something); meanwhile "absorbing or digesting food" metaphorically extends the seventh meaning (7)eliminate. E.g. "chīshuài" (to get rid of the opposite's chief when playing Chinese chess game); some organs are involved to help consuming energy, hence "Chi" derives the eight meaning 8consume. E.g. "chī lì" or "chījìn" (consume strength); however, these organs will load when working, so Chi gets the ninth meaning (9)bear. E.g. "chī déxiāo" (somebody can bear the pressure), "chībúzhù" (sb. or sth. cannot bear the weight); "bear" metaphorically extends the tenth meaning (10)receive or get (a passive voice). E.g. "chīkuī”(get the lost), "chī jīng” (get surprised), “chī pīpíng” (get criticized), "chī biě”(suffer a setback); the tenth meaning further extends the eleventh meaning $\mathrm{d}_{\mathrm{d}}$ a passive voice structure. E.g. "chī tā chǐxiào (be laughed by sb.) but this expression was often used in early modern Chinese but less used now. A relational graph about the prototype and extensive meanings of character "Chi" is as follows:

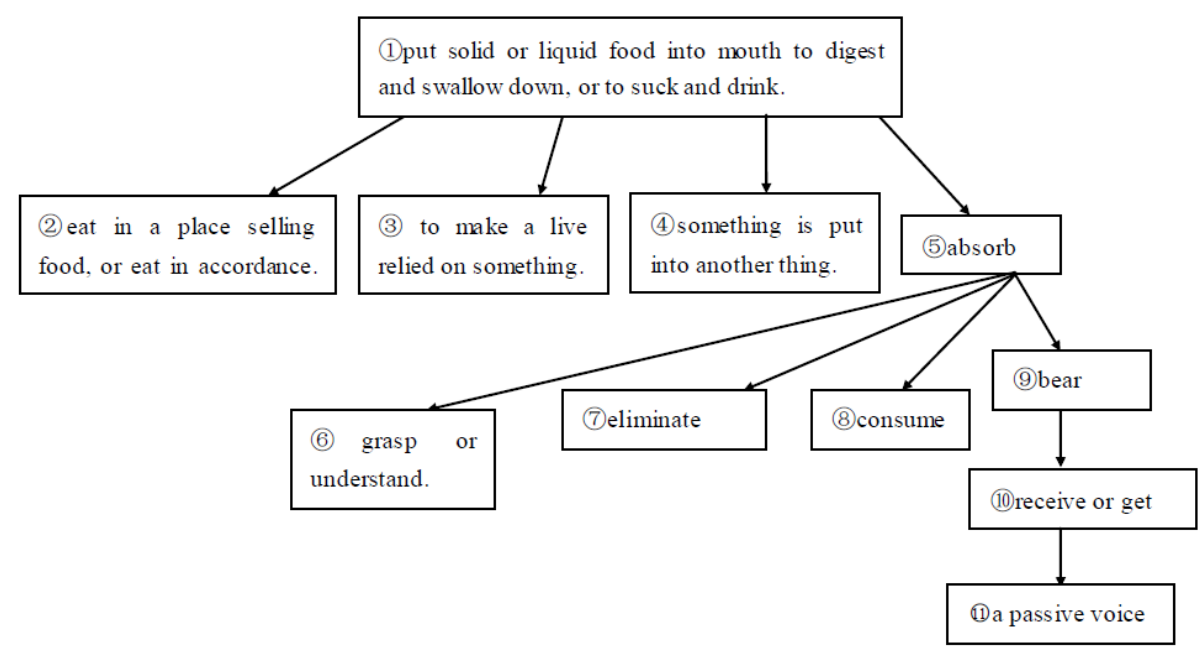

(Figure 1)

\section{WORD FORMATION ABOUT CHI}

J. L. Packard believes Chinese possesses both words and word formation. He defines word from morphologic standard as an independent slot owner, namely a flexible linguistic form, labeled as $\mathrm{X}^{\circ}$. He differentiates five lexical categories on the grounds of two criteria: (1) whether the word keeps totally its primitive meaning or not, or reflects its connotation; (2) whether grammatical information is usable in general.

(1) Conventional lexicalization. Constituents of the word in this category still remain their independent identity of meaning and grammar. E.g. the word "chīfàn" (eat food), "chī yào" (take medicine).

(2) Metaphorical lexicalization. Elements of the word in this category have lost their primitive meaning and got some metaphoric meanings, which keep their grammatical relationship. E.g. the word "chī cù" (be jealous), "chī kǔ" (bear the hardships).

(3) Asemantic lexicalization. Constituents of the word in this category should be cognized diachronically, since they in the synchronic level lose their metaphoric meanings. E.g. the word "chī tā chǐxiào" (be laughed at by him or her), "huǒ chē" (train), "wèn shì" (come out).

(4) Agrammatical lexicalization. Its constituents still have impact on the semantic word, but their grammatical relationship is no more in existence. E.g. "chī lì" (consume strength), "caǐ pái” (rehearse), "xué jiū” (scholastic) and so on.

(5) Complete lexicalization. Inter structure and primitive meanings of constituents in the word have become opaque. E.g. "chī xīn" (care about), "huā shēng" (peanut), "wù sè” (seek out) and so on.

From (1) to (5), the higher the lexical level is, the less information each character in words offers, and then its constituents are much easier to be influenced by phonetic attenuation. A common pattern is that some constituent in highly-lexicalized words loses its accent or tone. That's why "fŭ" in "chī dóu fu" (usually means a man flirt with a 
woman) and "dàn" in "chīyādan" (get a zero mark in the exam) become "fu" and "dan".

Lakoff advocates that category and concept structure can gradually form syntax structure based on image schema and then a series of metaphor mapping. Therefore, he summarized six basic syntax structures according to his seven image schemas. As a premise of syntax structure, morphemic structures are accordingly classified the following types:

1) Inclusive one can be described as container schema, such as the word "chī fàn" (eat);

2) Hierarchical one can be described as part-whole schema, such as the word "chī dúshî" (never share food or profits with others);

3) Referential or grammatical one can be described as link schema, such as "chīchī hēhē" (eat and drink);

4) "modifier-head" construction can be described as center-margin schema, such as "chī bùxiāo" (cannot bear);

5) "Verb + goal clause" one can be described as source-path-goal schema, such as "chū chéng" (go out of town);

6) "Distance" one can be described as linear schema, such as year, month and day;

What needs our attention is container schema, for example, "chī fàn" (eat) is such a contained structure. We understand "chī fàn" by pouring food into mouth, namely, regarding mouth as a container and food as stuff in the container; likewise, we consider "chī báifàn" (only eat the staple food/ not worth the salt), "chī xiánfàn"(be a loafer or sponger), "chī xiànchéngfàn" (food ready for eat/ unearned gain) as this type of word formation, and as variants of "chī fän" container schema.

Turner (Turner, 1996) states, relied on perception program, motor ability, and categorization of concepts and feelings, humans create abstract structures such as "image schema" or "dynamic link of differently distributed activities in the brain", and then map abstract story structure into basic syntax or morphemic structure via parable. Different concrete events can produce one abstract story structure, and then form abstract syntax or morphemic structure; that's to say, SVO or VO structure corresponds to story structure. For instance, "chī fàn" is a VO structure. In this structure, "Chi" is a verb, "fàn" is an inanimate object. The object can be abstract or animate, such as "chī jīng" (get surprised), "chī fùmǔ"(rely on parents), "chīshān" (if a man lives on a mountain, he will live off the mountain), "chīshuǔ̀" (if a man lives by the water, he will live off the water), "chīyòu"(fuel consumption), "chīshí" (have food), "chīzuř" (gluttony) and so on. We have known that "Chi" has a meaning of making a living by sth., so VO structure "chi+food" is metaphorically indicated as people who make a living by sth. For instances, "chī huángliáng" or "chī gōngzī" (officials work in government); "chī kāikǒufàn" (an actor); "chī fěnbǐhuî” (a teacher); "chīliáng" (a solider); "chi wăpiàn" (a landlord).

\section{REASOns Why Many Words about “Chi” EMERge ENDLESSLY}

\section{A. Image-schema}

Image is specific and experienced mental representation, which can be explained by feeling, sensation, and phenomenon. The progressive relation among them shows a general law of original stage known by people. Schema refers to a regular cognitive structure organized by processing experience and information in order to store long in memory. Humans acquire image schema when proceed interactivities with the objective world. Many a image schemas form a cognitive model (CM); lots of cognitive models constitute an ideal cognitive model (ICM). Therefore, humans, based on the above models, build category to get concept or meaning. Lakoff claims that image schema is formed mainly depending on feeling, sensation, and interactive experience; and it is an abstract structure prior to concept and language. He also discusses 7 kinds of image schemas: container (such as "in", "inside"), source-path-aim (such as "through"), connection (such as "link"), part-whole (such as "structure"), center-margin (such as "radiation"), up-down (such as "above", "below"), and front-back (such as "before", "after"). Image schemas are formed to be more categories and conceptions, especially abstract ones, and help humans acquire logical or reasoning ability via the extension or transfer of metaphoric or metonymic mechanism. From simple concept to complex concept, people gradually form a systematic concept structure in their mind. Reason why many words about "Chi" emerge endlessly is that people form an image schema about "chi" (specifically, container image schema), and then form a cognitive model, and make "chi" extend lots of relative words via metaphor mechanism. We can show it in the following figure:

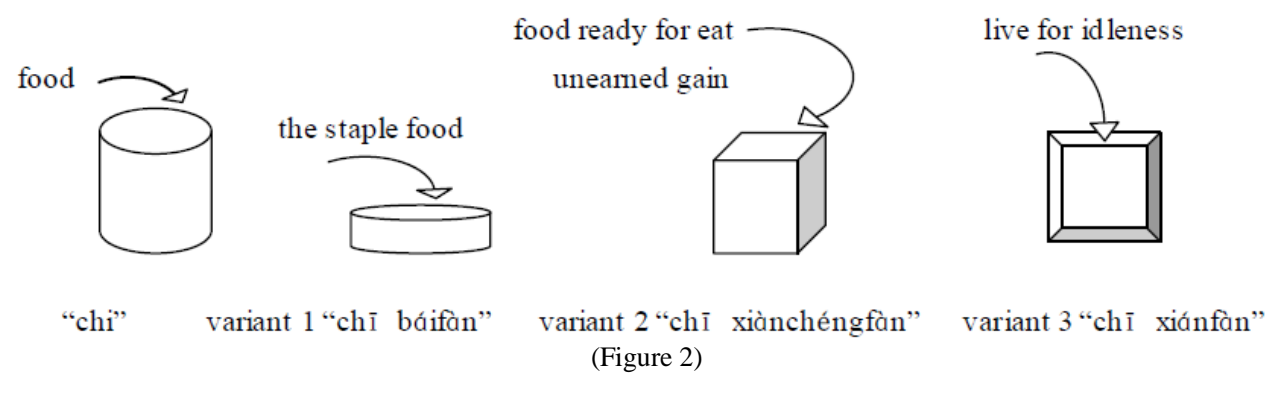

\section{B. Metaphor}

Metaphor refers to through mapping concept B replaces concept A in use of their relationship. The basic working principle of metaphor is the cognitive mechanism based on five tools (subject, tenor, vehicle, ground, and context). The 
nature of metaphor is similarity or analogy. We will take two examples: "chī cù" is considered to be jealous, "chī dóufu" is thought of as being molested by others. In a sentence "Tā bèi chī dóufu le", the subject is she, tenor is "dóufu" (concept B), vehicle is she (concept A), the ground is she is molested. As for the context, we can suppose a guy says some sexual innuendos, or somebody molests her on the bus and so on. But how to build this similarity between "dóufu" and she? The following figure shows the answer:

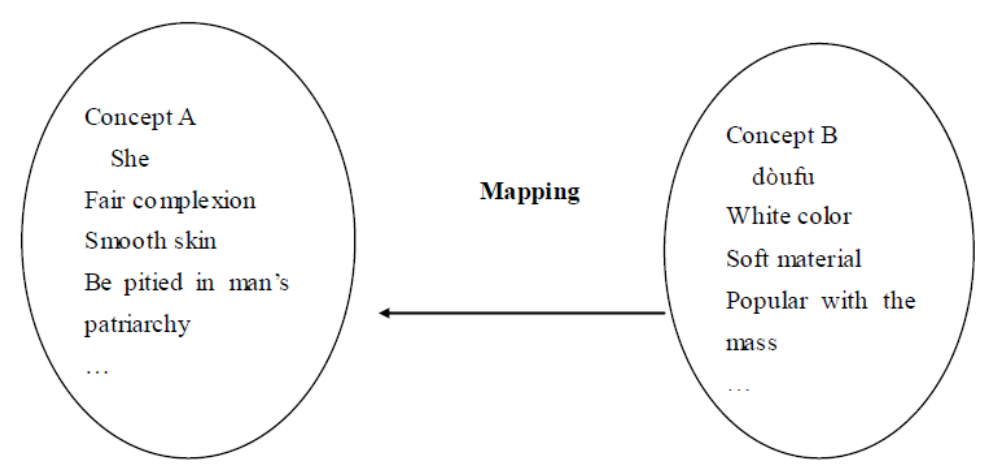

(Figure 3)

Lakoff classifies three kinds of metaphors in his book Metaphor We Lived By: structure metaphor, orientation metaphor and container metaphor. In container metaphor, people regard those abstract emotion, mental activity, event or state as concrete entities so that they can discuss, quantify or identify their features (Zhao Yanfang, 2004). The most representative one of entity metaphor is container metaphor, which considers people or organs of people, object, invisible and abstract activity or condition as a container. For examples, in a sentence "jīqì chī yòu", we visualize "jīqì" (machine) as a container, and imagine that oil is poured into this container. In the word "chī fàn", people or mouth is regarded as a container, and food is stored in this container, but "chī báifàn", "chī xiánfàn", "chī xiànchéngfàn" are variants of this container metaphor. It is a metaphoric mapping from concrete to abstract one, too.

\section{CONCLUSION}

A conclusion can be made from the above analysis: based on the principal meaning or a prototype, at least 10 margined meanings about "chi" can be extended via metaphoric mechanism to enrich the semantic category about "chi". Due to the metaphorical extension of word formation, constituents added behind verb "chi" is complex, and many meanings are derived to form a multi-meaning category of "chi" (especially container schema and V-O structure types). Based on prototype structure, we develop its usage via metaphor mechanism, and gradually form a dynamic and strongly adaptive word formation. Though limited capacity, the brain possesses delimited creation. This creation displays when humans enlarge valid memory by metaphor (rename something) in accordance with existing language cognitive form with the development of human's cognitive ability. It deserves notice that image schema plays a key role in people's renaming something, or mapping a concept into another concept, particularly mapping from concrete domain to abstract domain. All kinds of image schemas are interwoven to constitute our ample experience network and concept structures. Hence, this thesis holds that image schema and metaphor can explain why people create so many words about "chi" and its multi meanings.

At the same time, the significances of grasping cognitive linguistics display from two sides: firstly, it can help and guide Chinese language teaching for foreigners. If Chinese teachers know the relationship among these meanings of a word with multi meanings is mapping from concrete to abstract one, he or she can guide foreign students to know the rule of developing words and intrinsic developing mechanism so that these students improve their comprehensive ability. What's more, knowing metaphor helps them to better understand some special expressions, and finally improve their reading or appreciation ability. This point can bridge two countries' culture as well. Secondly, it has guidance to natural language process and machine translation. For instance, if we systematically collect words about "chi" and their corresponded meanings as different language chunks, which are stored into computer system to transfer into natural language, letting machine chooses a suitable words according to different contexts when translating automatically.

\section{REFERENCES}

[1] Dictionary Editorial Office, Institute of Language, Chinese Academy of Social Sciences (Eds). (2005). Modern Chinese Dictionary. Beijing: Commercial Press.

[2] J. L. Packard (editor). Yang Yiming \& Yu Guangwu (review). (2003). A review of the Morphology of Chinese: A Linguistic and Cognitive Approach. Modern Linguistics. 21, P64-72

[3] Leech Geoffrey (editor). Li Ruihua \& Yang Zijian (trans.). (1987). Semantics. Shanghai: Shanghai Foreign Language Education Press.

[4] Turner. (1996). Blending as a Central Process of Grammar. In Conceptual Structure, Discourse and Language. Standford: CSLT Publications. P113-129. 
[5] Wang Yin. (2007). Cognitive Linguistics. Shanghai: Shanghai Foreign Language Education Press.

[6] Wu Shan \& Li Fuyin. (2008). A Cognitive Semantic Analysis of the Chinese Polysemous Word "Li". In Journal of Beijing University of Aeronautics and Astronautics (Social Sciences Edition). 21, P1-4

[7] Yang Zijian. (2004). English-Chinese Comparative Study and Translation. Shanghai: Shanghai Foreign Language Education Press.

[8] Zhao Yanfang. (2001). An Introduction to Cognitive Linguistics. Shanghai: Shanghai Foreign Language Education Press.

[9] Zhao Yuanren. (1975). The Concept, Structure and Rhythm of Chinese Word. Selection of Zhao Yuanren's Linguistics Papers. Beijing: Tsinghua University Press.

Bin Wang was born in Sichuan, China in 1968. He received his PH.D. degree in linguistics from Beijing Normal University, China in 2010.

$\mathrm{He}$ is currently a professor in the School of Foreign Languages, Beijing University of Posts and Telecommunications, Beijing, China. His research interests include linguistics and translation.

Fan Zhang was born in Hubei, China in 1986. She received his M.A. degree in English linguistics and literature from Beijing University of Posts and Telecommunications, China in 2011.

She is currently a graduate of Beijing University of Posts and Telecommunications, Beijing, China. Her research interests include linguistics and American literature. 